OPEN ACCESS

Edited by:

Rossano Bolpagni,

Institute for the Electromagnetic Detection of the Environment

(IREA), Italy

Reviewed by:

Georgios Liakopoulos,

Agricultural University of Athens,

Greece

Bishal Tamang,

University of Minnesota Twin Cities,

United States

${ }^{*}$ Correspondence:

Balázs András Lukács

lukacs.balazs@okologia.mta.hu

Specialty section: This article was submitted to Functional Plant Ecology,

a section of the journal

Frontiers in Plant Science

Received: 05 September 2019 Accepted: 12 December 2019

Published: 07 February 2020

Citation:

Szabó S, Peeters ETHM, Borics G,

Veres $S$, Nagy PT and Lukács BA

(2020) The Ecophysiological

Response of Two Invasive Submerged

Plants to Light and Nitrogen.

Front. Plant Sci. 10:1747.

doi: $10.3389 /$ fpls.2019.01747

\section{The Ecophysiological Response of Two Invasive Submerged Plants to Light and Nitrogen}

\author{
Sándor Szabó ${ }^{1}$, Edwin T. H. M. Peeters ${ }^{2}$, Gábor Borics ${ }^{3}$, Szilvia Veres ${ }^{4}$, \\ Péter Tamás Nagy $^{5}$ and Balázs András Lukács ${ }^{6 *}$
}

${ }^{1}$ Department of Biology, University of Nyíregyháza, Nyíregyháza, Hungary, ${ }^{2}$ Aquatic Ecology and Water Quality Group, Wageningen University, Wageningen, Netherlands, ${ }^{3}$ Department of Tisza River Research, Danube Research Institute, MTA Centre for Ecological Research, Debrecen, Hungary, ${ }^{4}$ Department of Agricultural Botany, Crop Physiology and Biotechnology, Institute of Crop Sciences, University of Debrecen, Debrecen, Hungary, 5 Institute of Water and Environmental Management, University of Debrecen, Debrecen, Hungary, ${ }^{6}$ Wetland Ecology Research Group, Danube Research Institute, MTA Centre for Ecological Research, Debrecen, Hungary

Two submerged Elodea species have small differences in their ecophysiological responses when exposed to individual environmental factors. However, field observations showed that under eutrophic conditions with low light availability, Elodea canadensis could be displaced by Elodea nuttallii. Here we investigated the combined effect of environmental factors on the ecophysiological response of the two species in order to explain the differences in their invasion successes. We cultivated the plants in aquaria containing five different nitrogen $(\mathrm{N})$ concentrations and incubated at five different light intensities. For both species increasing nitrogen concentrations resulted in increased relative growth rate, chlorophyll concentration, and actual photochemical efficiency of photosystem II ( $\Phi_{\text {PSII }}$ ), however, they produced less roots. Lowering light intensity resulted in a lower relative growth rate, root production, and nutrient removal. In contrast, chlorophyll concentration in the leaves, and $\Phi_{\mathrm{PSII}}$ increased. The main difference between the two Elodea species was that the light compensation point $\left(I_{\mathrm{c}}\right)$ and weight loss in the dark were significantly higher and photochemical efficiency and chlorophyll concentration were significantly lower for $E$. canadensis than for $E$. nuttallii, indicating that the latter can survive under much more shady and hypertrophic conditions. The change in nitrogen concentration of the media and in tissue concentration of the plants indicated that E. nuttallii has a higher nitrogen removal capacity. The ecophysiological differences between the two species can be an explanation for invasion success of $E$. nuttallii over E. canadensis and thus may explain why the latter is replaced by the first.

Keywords: Elodea, growth rate, interaction, nutrient removal, photochemical efficiency 


\section{INTRODUCTION}

Light and nutrient availability are key factors governing the distribution and growth of submerged macrophytes in aquatic ecosystems (Chambers, 1987; Chambers and Kalff, 1987; Best et al., 2001). Eutrophication changes the availability of nutrients and light for submerged macrophytes and this might be beneficial for some macrophytes but harmful to others (Cao et al., 2011). Rooted submerged plants grow under relatively low light conditions at the start of the growing season, and their growth is accelerated when temperature rises. Due to their apical elongation, they grow towards the water surface and become exposed to higher light levels which is favorable for photon capture (Kuni, 1982). The relative competitive advantage of submerged macrophytes depends on their capacity to take up nutrients and to capture light (Szabó et al., 2010). The sooner a species reaches the higher light level, the better this species can shade out and finally displace others (Barrat-Segretain, 2005), and this is especially important in eutrophic and turbid waters. Light availability for submerged plants is not only influenced by shading of neighboring plants but also by the presence of freefloating vegetation (Scheffer et al., 2003; Morris et al., 2004; Lu et al., 2013; van Gerven et al., 2015). Floating algal bed, planktonic and periphytic algae can additionally reduce inherently poor light conditions under the water and lead to the decline of aquatic vegetation (Phillips et al., 1978; Hillebrand, 1983). Ultimately, plants that have a lower light compensation point or have a higher shade tolerance are expected to be better survivors in turbid water or under the shade of floating macrophytes. Consequently, eutrophication opens the window of opportunity for submerged macrophytes that have those traits (James et al., 1999). Frequently, species with those traits invade new regions where they are more competitive than native species (Vilà and Weiner, 2004; Espinar et al., 2015).

An interesting case is the introduction of congeneric exotic water plant species like Elodea canadensis and Elodea nuttallii. Both species are native to North America and were introduced to Europe. E. canadensis arrived to the British Isles in the middle of the 19th century. After the first records of E. nuttallii in 1966, this new invader spread rapidly all over England and displaced $E$. canadensis even at sites where the latter was well-established (Lund, 1979; Simpson, 1984; Simpson, 1990). This displacement was relatively rapid, taking place over a period of years, and is consistent with displacements elsewhere in Western Europe (Barrat-Segretain, 2001). From 1870 onwards E. canadensis was also present in Central European waters while E. nuttallii arrived in the beginning of the 21th century in Central European waters i.e. Slovakia (Ot'ahel'ová and Valachovič, 2002), Hungary (Sipos et al., 2003; Király et al., 2007), Croatia, (Grudnik and Germ, 2013; Grudnik et al., 2014; Kočic et al., 2014) and it was questionable whether E. canadensis would be displaced.

Several authors suggested that the displacement of $E$. canadensis by $E$. nuttallii was due to differences in their ecophysiological responses to environmental variables. However, observed differences in their ecophysiological responses like growth rate along a single gradient of temperature (Kuni, 1982; Kuni, 1984), nitrogen and phosphorus accumulation (Robach et al., 1995; James et al., 2006), photosynthesis and respiration (James et al., 1999), allelopathic activity against algae (Erhard and Gross, 2006; Lürling et al., 2006) all seemed too slight to induce such a displacement. Also, the tiny differences in life-history traits like fragment regeneration, colonization, and palatability seem also not plausible to explain the observed displacement of $E$. canadensis by $E$. nuttallii (Barrat-Segretain et al., 2002; James et al., 2006). Interestingly, Barrat-Segretain (2005) concluded from an experiment that $E$. nuttallii seemed to be the better competitor of the two for light. Furthermore, data from The Netherlands and Central European waters suggested that the replacement of E. canadensis by E. nuttallii was especially pronounced in ditches in agricultural areas, where total nitrogen input was much higher (Knoben and Peeters, 1997; Király et al., 2007; Grudnik et al., 2014). A recent study showed that light and nitrogen jointly triggered the development of those phenotypic characteristics that makes E. nuttallii a more successful invader in eutrophic waters than E. canadensis (Szabó et al., 2019). These two factors (light availability and nitrogen) are strongly related to eutrophication. The responses to these factors separately have been well documented (light: SandJensen and Madsen, 1991; Madsen and Sand-Jensen, 1994; Angelstein and Schubert, 2009; nutrients: Barrat-Segretain, 2004; James et al., 2006), but their combined impact has been investigated only on the phenotypic characteristics (Szabó et al., 2019).

In this study we go further. We hypothesize that small ecophysiological differences between the two Elodea species become more pronounced under increasing nitrogen concentrations and decreasing light conditions and this may contribute to the invasion success of $E$. nuttallii. The present study aims to evaluate this hypothesis by investigating the combined effects of light and nitrogen on the ecophysiological responses of the two Elodea species in an indoor experiment. Since both Elodea species may strongly modify light conditions if they are grown in co-cultures (Barrat-Segretain and Elger, 2004; Barrat-Segretain, 2005), both species were cultivated separately in order to exclude these effects.

\section{METHODS}

\section{Plant Collection, Preincubation}

E. nuttallii shoots were collected from the Eastern Principal Channel, (N 47.860911 ${ }^{\circ}$, E 21.382270 $)$ and E. canadensis from the River Bodrog (N $48.172491^{\circ}$, E $\left.21.363358^{\circ}\right)$ Hungary. The selected apical shoots were preincubated for 18 days under experimental conditions. Shoots were set in five plastic boxes containing 20-L culture medium (Barko and Smart, 1985). The supply of phosphorus was ensured by adding $\mathrm{K}_{2} \mathrm{HPO}_{4}$ to the final concentration to $0.2 \mathrm{mg} \mathrm{P} \mathrm{L}^{-1}$ and supply of micronutrients by adding TROPICA Supplier micronutrient solution. Final concentration of the solutions for nitrogen varied from oligotrophic $\left(0.05 \mathrm{mg} \mathrm{L}^{-1}\right)$, mesotrophic $\left(0.25 \mathrm{mg} \mathrm{L}^{-1}\right)$, eutrophic $\left(0.5 \mathrm{mg} \mathrm{L}^{-1}\right)$, and hypertrophic $\left(2.5\right.$ and $\left.5 \mathrm{mg} \mathrm{L}^{-1}\right)$ 
among the treatments by adding $\mathrm{NH}_{4} \mathrm{NO}_{3}$ stock solution to the medium (Szabó et al., 2019). The culture medium was renewed every second day. The length of the shoots was reduced to $65 \mathrm{~mm}$ after preincubation. Subsamples of three initial shoots of each species from each nitrogen concentration was measured for fresh and dry weight $\left(W_{0}\right)$.

\section{Laboratory Experiment}

Elodea plants (three shoots) were set on a plastic grid and placed in 2-L aquaria containing the culture media described above. All aquaria were put into a controlled temperature $\left(23-25^{\circ} \mathrm{C}\right)$ water bath with renewing of the medium every second day. For both Elodea species, the five different $\mathrm{N}$ treatments were incubated in a 16:8 $\mathrm{h} \mathrm{L} / \mathrm{D}$ regime at five different light intensities varying from complete dark to well-illuminated conditions: $0,10,28,80$, and $180 \mu \mathrm{mol} \mathrm{m} \mathrm{s}^{-2}$ PAR photon flux density (Szabó et al., 2019). Illumination was carried out by $400 \mathrm{~W}$ metal halogen lamps and by using plastic gauze above the aquaria. Each treatment was replicated four times meaning that 200 aquaria were used. The plants were harvested after 12 days of incubation.

\section{Relative Growth Rate}

Six leaves were taken from each shoot (18 leaves per aquarium) and divided into two portions. One portion was used for fresh weight and chlorophyll determination, the other for dry weight determination $\left(W_{\text {leave }}\right)$. For a single measurement per aquarium, dry weight of the three shoots and their roots of each aquarium were measured. Samples were dried at $65^{\circ} \mathrm{C}$ for 2 days. The rootshoot ratios were expressed on a dry-weight basis. The relative growth rate (RGR) of the plants was calculated as RGR $=\left(\ln W_{t}-\right.$ $\left.\ln W_{0}\right) / t$, where $W_{0}$ represents the initial and $W_{t}$ the final dry weight (in g) of the three plants in each aquarium and $t$ is the growing time in days. The light compensation point for growth $I_{\mathrm{c}}$ $\left(\mu \mathrm{mol} \mathrm{m} \mathrm{m}^{-2} \mathrm{~s}^{-1}\right.$ ) was estimated according to Sand-Jensen and Madsen (1991). Weight loss in the dark $\left(\mathrm{RGR}_{\mathrm{d}}, 10^{-3}\right.$ day $\left.^{-1}\right)$ was measured for plants incubated in the dark for 12 days $(0 \mu \mathrm{mol}$ $\left.\mathrm{m}^{-2} \mathrm{~s}^{-1}\right)$ compared to initial weight $\left(W_{0}\right)$.

\section{Photochemical Efficiency}

The actual photochemical efficiency of photosystem II ( $\left.\Phi_{\text {PSII }}\right)$ was measured by means of chlorophyll fluorescence with MINIPAM fluorometer (Walz, Germany). The measurement on the plants was carried out using the middle part of the apical shoots from each aquarium as described by Snel et al. (1998). The shoots were placed in a $25 \mathrm{ml}$ glass tube and faced to the common end of the optical fiber of the fluorometer. The actual photochemical efficiency of photosystem II was calculated as $\Delta F / F_{\mathrm{m}}{ }^{\prime}=\left(F_{\mathrm{m}}{ }^{\prime}-\right.$ $\left.F_{\mathrm{s}}\right) / F_{\mathrm{m}}{ }^{\prime}$ with $F_{\mathrm{m}}{ }^{\prime}$ the maximal fluorescence and $F_{\mathrm{s}}$ is the steadystate fluorescence of the illuminated shoots (Genty et al., 1989). Steady-state fluorescence $\left(F_{\mathrm{s}}\right)$ was achieved after exposure to actinic light for $10 \mathrm{~min}$. Maximum-fluorescence under steadystate conditions $\left(F_{\mathrm{m}}{ }^{\prime}\right)$ was determined by applying pulses of the saturating light when the actinic light was on (Marwood et al., 2001). The duration of the saturating light pulses was $500 \mathrm{~ms}$ and the pulses were given every $60 \mathrm{~s}$. The average of three chlorophyll fluorescence measurements represented the photochemical efficiency of the plants in each aquarium.

\section{Chlorophyll Concentration}

For a single measurement per aquarium, chlorophyll of the nine leaves from each aquarium was extracted in a test tube containing $6 \mathrm{ml} 95 \%$ ethanol for $24 \mathrm{~h}$ at $4^{\circ} \mathrm{C}$ in the dark. Total chlorophyll concentrations were measured by spectrophotometry (T80+ Spectrometer, PG Instruments Limited, UK) and were calculated according to Lichtentaler (1987). Leaf chlorophyll concentrations were expressed on a dry-weight basis of the leaves ( $\left.W_{\text {leave }}\right)$.

\section{Elemental Composition}

Samples were taken from the water at the end of the experiment. We first recorded $\mathrm{pH}$ and thereafter samples were filtered (mesh size $0.45 \mu \mathrm{m})$ and analyzed for $\mathrm{NO}_{3}{ }^{-}-\mathrm{N}, \mathrm{NO}_{2}{ }^{-}-\mathrm{N}, \mathrm{NH}_{4}{ }^{+}-\mathrm{N}$ (Technicon Auto Analyzer). At the end of the experiment nitrogen and carbon concentration of the dried plants had been grown at $10-180 \mu \mathrm{mol} \mathrm{m} \mathrm{m}^{-2} \mathrm{~s}^{-1}$ light intensity (160 samples) was analyzed by dry combustion using a Vario Max Cube elemental analyzer (Elementar GMBH, Germany).

\section{Statistical Analysis}

Normality of the variables was checked by the KolmogorovSmirnov test. RGR, chlorophyll concentration of the leaves, root-shoot ratio and nitrogen concentration of the plants were all normally distributed $(P>0.05)$. Data of actual photochemical efficiency of photosystem II and $\mathrm{C} / \mathrm{N}$ ratio were log-transformed for normality. A general linear model was used to test the significance of the factors (light, nitrogen, species identity) and their interactions on the variables. Residuals were checked for normality and homogeneity of variances was evaluated by Levene's test. Tukey post-hoc tests were used to evaluate which treatments differed from each other. Pairwise comparisons were used to test the variables for significant differences between species where the mean difference $(\mathrm{MD})+$ standard error were indicated. All analyses were done using SPSS 16.0 software.

\section{RESULTS}

\section{Relative Growth Rate}

Species identity, nitrogen concentration, light intensity, and their interactions significantly influenced the RGR (Table 1). The RGR of both Elodea species increased with increasing light intensity and with increasing $\mathrm{N}$ concentration (Figure 1). Furthermore, pairwise comparisons showed that the differences between the species were statistically significant (Table 1). Growth seemed to be saturated above $80 \mu \mathrm{mol} \mathrm{m} \mathrm{m}^{-2} \mathrm{~s}^{-1}$ for $E$. nuttallii at all $\mathrm{N}$ concentrations except for the lowest one, and in contrast, light stimulated the growth of E. canadensis up to the highest light intensity $\left(180 \mu \mathrm{mol} \mathrm{m} \mathrm{m}^{-2} \mathrm{~s}^{-1}\right)$. The RGR measured at the highest light intensity was significantly higher for $E$. canadensis than for E. nuttallii (MD $0.025 \pm 0.002$ Pairwise comparisons $P<0.001)$. However, under low light levels $(0-10$ $\left.\mu \mathrm{mol} \mathrm{m} \mathrm{m}^{-2} \mathrm{~s}^{-1}\right)$ E. nuttallii showed a significantly higher growth rate than E. canadensis (MD $0.012 \pm 0.002$ Pairwise comparisons $P<0.001$ ). Weight loss in the dark differed significantly (pairwise 
TABLE 1 | Analysis of variance of the relative growth rate (RGR), actual photosynthetic efficiency of PSII, chlorophyll concentration (Chl CC), root-shoot ratio of Elodea (E. canadensis, E. nuttallii) cultures grown in aquaria under different nitrogen concentrations in the water combined with different light intensities.

\begin{tabular}{|c|c|c|c|c|}
\hline Source/Trait & $d f$ & Mean Square & $\boldsymbol{F}$ & Sig. \\
\hline \multicolumn{5}{|l|}{ RGR } \\
\hline Species & 1 & 0.00 & 7.91 & 0.01 \\
\hline Light & 4 & 0.10 & $1,739.81$ & $<0.01$ \\
\hline Nitrogen & 4 & 0.01 & 112.24 & $<0.01$ \\
\hline Light * Species & 4 & 0.00 & 57.06 & $<0.01$ \\
\hline Nitrogen * Species & 4 & 0.00 & 4.72 & $<0.01$ \\
\hline Light * Nitrogen & 16 & 0.00 & 8.94 & $<0.01$ \\
\hline Error & 150 & 0.00 & & \\
\hline \multicolumn{5}{|c|}{ Photosynthetic efficiency } \\
\hline Species & 1 & 0.01 & 32.21 & $<0.01$ \\
\hline Light & 4 & 0.86 & $1,903.57$ & $<0.01$ \\
\hline Nitrogen & 4 & 0.06 & 134.30 & $<0.01$ \\
\hline Light $\times$ Species & 4 & 0.03 & 70.56 & $<0.01$ \\
\hline Nitrogen $\times$ Species & 4 & 0.00 & 9.44 & $<0.01$ \\
\hline Light $\times$ Nitrogen & 16 & 0.01 & 17.82 & $<0.01$ \\
\hline Error & 150 & 0.00 & & \\
\hline \multicolumn{5}{|l|}{ Chl cc } \\
\hline Species & 1 & $1,975.04$ & 544.42 & $<0.01$ \\
\hline Light & 4 & 892.66 & 246.06 & $<0.01$ \\
\hline Nitrogen & 4 & $2,112.38$ & 582.28 & $<0.01$ \\
\hline Light $\times$ Species & 4 & 49.04 & 13.52 & $<0.01$ \\
\hline Nitrogen $\times$ Species & 4 & 77.45 & 21.35 & $<0.01$ \\
\hline Light $\times$ Nitrogen & 16 & 54.07 & 14.90 & $<0.01$ \\
\hline Error & 150 & 3.63 & & \\
\hline \multicolumn{5}{|l|}{ Root-shoot ratio } \\
\hline Species & 1 & 0.02 & 144.82 & $<0.01$ \\
\hline Light & 4 & 0.12 & 841.85 & $<0.01$ \\
\hline Nitrogen & 4 & 0.02 & 161.74 & $<0.01$ \\
\hline Light $\times$ Species & 4 & 0.00 & 18.45 & $<0.01$ \\
\hline Nitrogen $\times$ Species & 4 & 0.00 & 15.86 & $<0.01$ \\
\hline Light × Nitrogen & 16 & 0.00 & 33.89 & $<0.01$ \\
\hline Error & 150 & 0.00 & & \\
\hline
\end{tabular}

comparisons $P<0.001)$ between the two Elodea species and was higher for E. canadensis than for E. nuttallii (MD $0.015 \pm 0.002$ ). The increase of $\mathrm{N}$ concentration from 2.5 to $5 \mathrm{mg} \mathrm{L}^{-1}$ did not cause differences in the growth rate of either species (Figure 1).
The light compensation point $\left(I_{\mathrm{c}}\right)$ decreased sharply with increasing $\mathrm{N}$ concentration and was significantly higher (MD $5.500 \pm 2.131$ pairwise comparisons, $P=0.033$ ) for $E$. canadensis than for E. nuttallii (Figure 2).

\section{Photochemical Efficiency}

Light intensity, nitrogen concentration, and their interactions had a significant impact on the actual photochemical efficiency of photosystem II ( $\left.\Phi_{\text {PSII }}\right)$ (Table 1). Both Elodea species showed the highest $\Phi_{\text {PSII }}$ at low and medium light levels (Figure 3, 0-28 $\mu \mathrm{mol} \mathrm{m} \mathrm{m}^{-2} \mathrm{~s}^{-1}$ ) and the lowest $\Phi_{\text {PSII }}$ at the highest light level within each nitrogen concentration. Actual photochemical efficiency of photosystem II increased significantly at lower light intensities $(P<0.001)$ and at higher nitrogen



FIGURE 2 | Light compensation point $\left(I_{\mathrm{C}}\right)$ of $E$. canadensis and E. nuttallii cultures grown at different nitrogen concentrations. $I_{c}$ values were estimated according to Sand-Jensen and Madsen (1991).
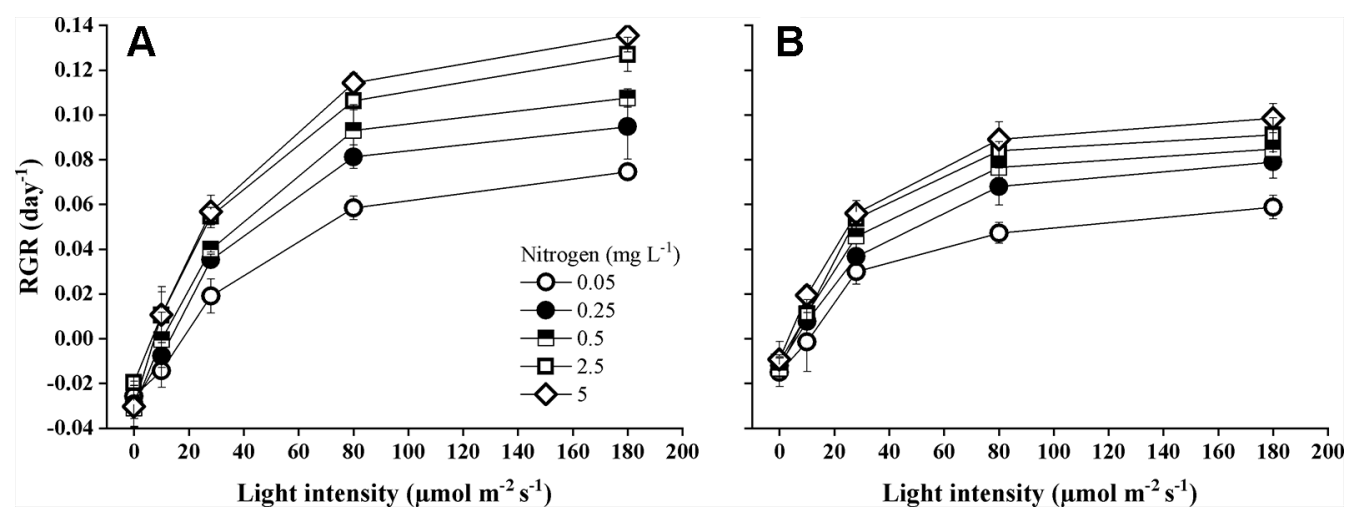

FIGURE 1 | Relative growth rate (RGR) of E. canadensis (A) and $E$. nuttallii $\mathbf{( B )}$ cultures grown at different nitrogen concentrations and light levels (mean $\pm \mathrm{SD}, n=4)$. 

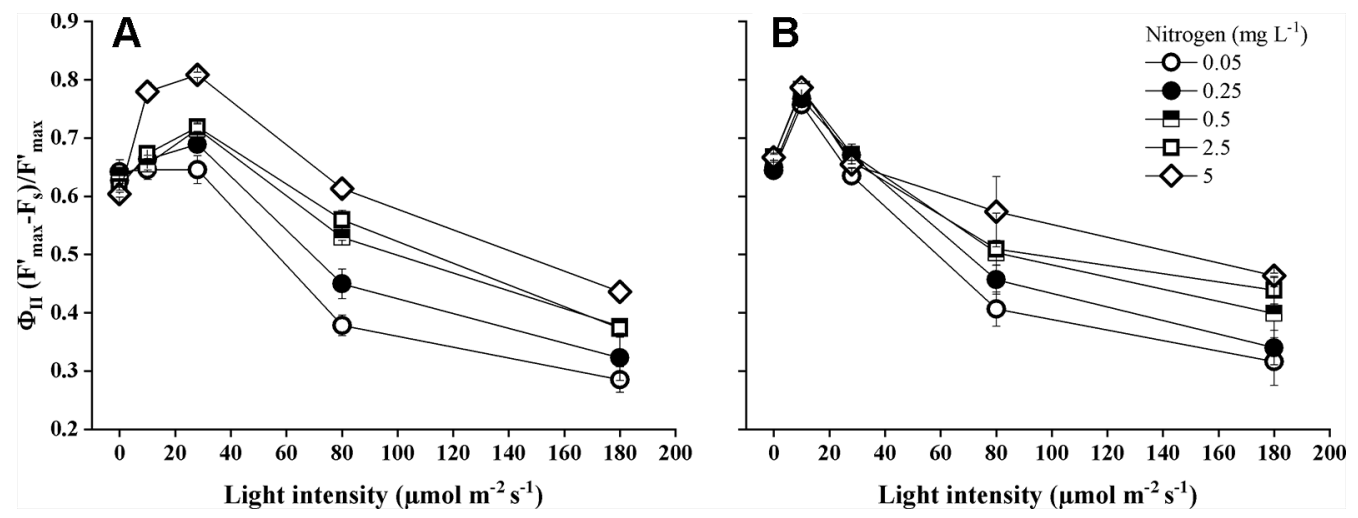

FIGURE 3 | Actual photochemical efficiency of photosystem II ( $\left.\Phi_{\|}\right)$of $E$. canadensis (A) and E. nuttallii (B) cultures grown at different nitrogen concentrations and light levels (mean $\pm \mathrm{SD}, n=4$ ).

concentrations $(P=0.022)$. Photochemical efficiency differed significantly (pairwise comparisons $P<0.001$ ) between the two Elodea species and was higher for E. nuttallii than for $E$. canadensis (MD $0.017 \pm 0.003)$. Under low light levels (0-10 $\mu \mathrm{mol} \mathrm{m} \mathrm{s}^{-1}$ ), the difference for $\Phi_{\mathrm{PSII}}$ between the two Elodea species was even higher (MD $0.063 \pm 0.003$ ) (Figure 3).

\section{Total Chlorophyll Concentration}

Species identity, nitrogen concentration, light intensity, and their interactions significantly influenced total chlorophyll concentrations of the leaves (Table 1). Chlorophyll concentration was significantly higher (pairwise comparisons, $P<0.001$ ) in $E$. nuttallii than in $E$. canadensis (MD $6.28 \pm 0.27$ ). According to the Tukey test, both species demonstrated that increasing light intensity resulted in significantly $(P<0.001)$ lower chlorophyll concentrations, but this was also depending on the $\mathrm{N}$ concentration (Figure 4). Increasing the light intensity, E. canadensis showed a much stronger drop in chlorophyll concentration than $E$. nuttallii. Lowering the nitrogen concentration significantly $(P<0.001)$ reduced chlorophyll concentration (Table 1) in both species (Figure 4).

\section{Root-Shoot Ratio}

Species identity, light intensity, and the statistical interaction between light intensity and $\mathrm{N}$ concentrations had a significant effect on root-shoot ratios (Table 1). Root-shoot ratios were the highest $(0.17-0.22)$ at lower nitrogen concentrations $(0.25-0.5$ $\mathrm{mg} \mathrm{N} \mathrm{L}{ }^{-1}$ ) and higher light intensities for both species (Figure 5). E. canadensis had significantly higher (pairwise comparisons, $P<$ 0.001 ) root-shoot ratio than $E$. nuttallii (MD $0.021 \pm 0.002)$. The difference in root-shoot ratios was even higher (MD $0.046 \pm$ $0.006, P<0.001)$ under the highest light level $\left(180 \mu \mathrm{mol} \mathrm{m}^{-2} \mathrm{~s}^{-1}\right)$.

\section{Chemical Composition of the Plants}

Nitrogen concentration of the water, light intensity, and their interactions significantly influenced carbon/nitrogen ratio $(\mathrm{C} / \mathrm{N}$ ratio) of the plants (Supplementary Table 1). C/N ratio of both Elodea species decreased with increasing $\mathrm{N}$ concentration and with decreasing light intensity (Figure 6). At the highest light intensity, tissue $\mathrm{N}$ concentration $\left(\mathrm{mg} \mathrm{N} \mathrm{g}^{-1}\right)$ was significantly higher for E. nuttallii than for E. canadensis (MD $6.043 \pm 0.342$, pairwise comparisons $P<0.001$ ) (Figure 7).
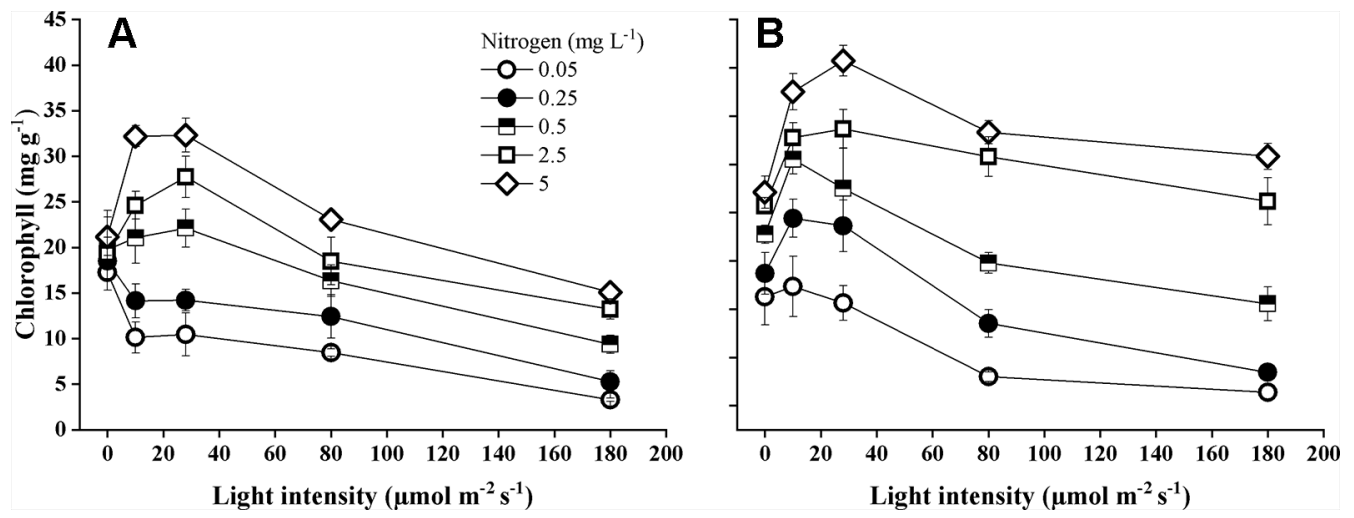

FIGURE 4 | Chlorophyll concentration $\left(\mu \mathrm{g} \mathrm{mg}^{-1}\right)$ in the leaves of $E$. canadensis (A) and E. nuttallii (B) cultures grown at different nitrogen concentrations and light levels, (mean $\pm \mathrm{SD}, n=4)$. 

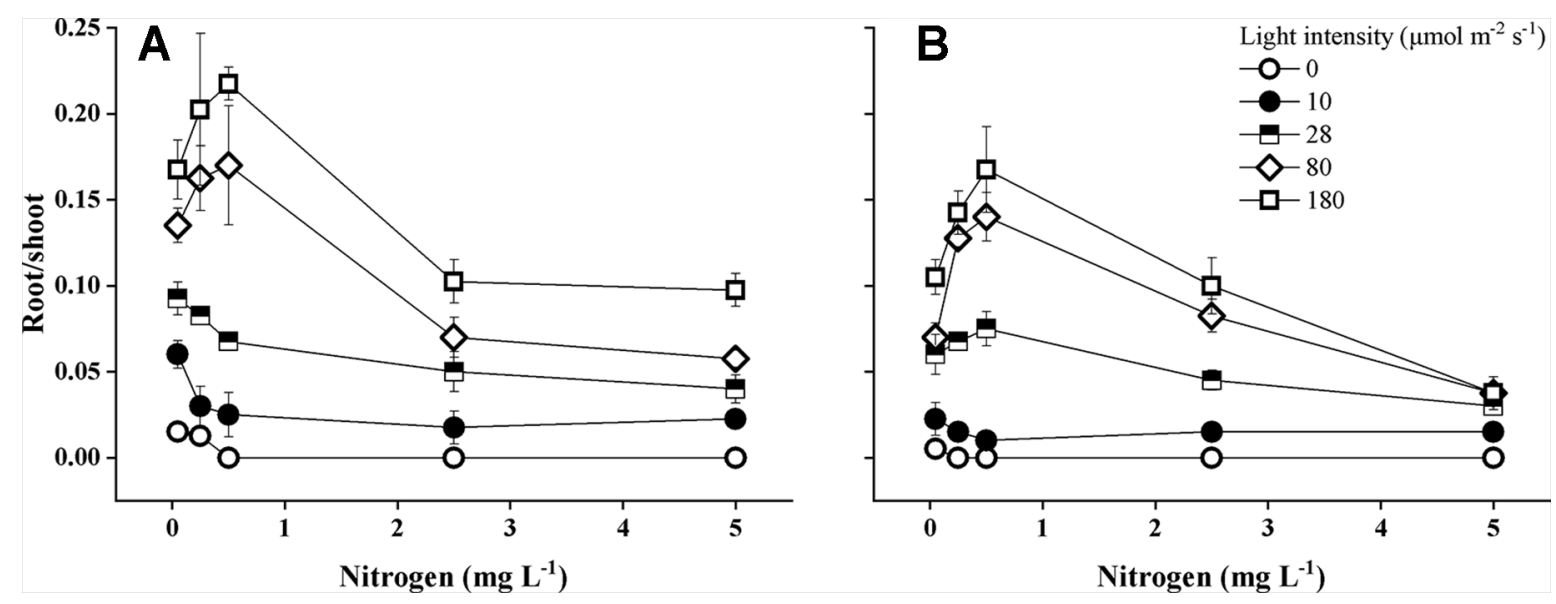

FIGURE 5 | Root-shoot ratio of Elodea canadensis (A) and E. nuttallii (B) cultures grown at different nitrogen concentrations and light levels, (mean \pm SD, $n=4)$.
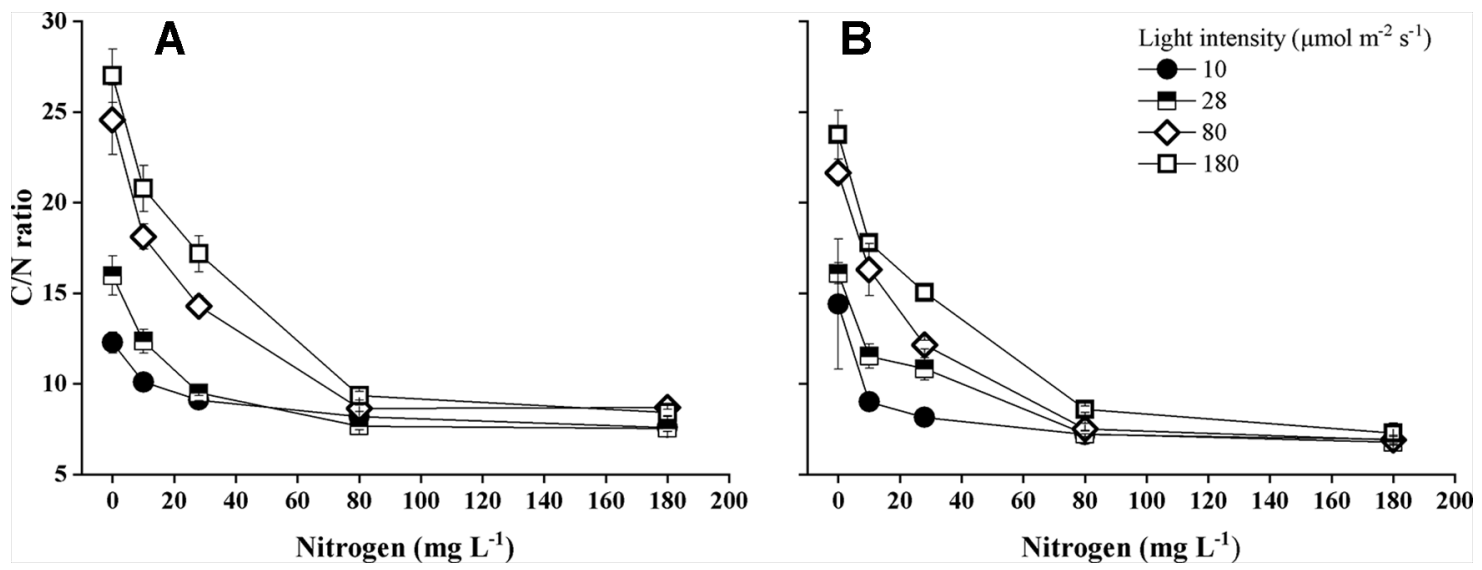

FIGURE 6 | Carbon/nitrogen ratio (C/N ratio) of E. canadensis (A) and E. nuttallii (B) cultures grown at different nitrogen concentrations and light levels (mean \pm SD, $n=4)$.

\section{Chemical Composition of Water}

Total nitrogen removal by the two examined Elodea species (expressed by a drop in total nitrogen concentration of the water) decreased with decreasing light intensities. The final $\mathrm{N}$ concentration was significantly lower with E. nuttallii than with E. canadensis (pairwise comparison $P<0.001$; MD 0.451 \pm 0.021 ) when initial concentration was higher than $0.25 \mathrm{mg} \mathrm{N}$ $\mathrm{L}^{-1}$. Under the highest light intensity and the highest initial nitrogen level $\left(5 \mathrm{mg} \mathrm{L}^{-1}\right)$, the difference in the final nitrogen concentration between the two species was even higher (pairwise comparison $P<0.001$; MD $2.558 \pm 0.057$ ) (Figure 8). At the highest light intensity, E. nuttallii increased the $\mathrm{pH}$ more markedly (10.41) than E. canadensis (9.74). We found the highest at the highest light level. The $\mathrm{pH}$ decreased drastically at reduced light intensities.

\section{DISCUSSION}

\section{Interactive Effects of Light and Nitrogen}

Interactive effects of various factors on plant growth have previously been observed more often for light and inorganic carbon, and for nitrogen and inorganic carbon (Madsen and Sand-Jensen, 1994; Madsen et al., 1998), light and temperature (Barko et al., 1982), light and nitrogen (Szabó et al., 2019), temperature and phosphorus (Peeters et al., 2013), and nitrogen and phosphorus (Cao et al., 2011; Li et al., 2016). In this study, light and nitrogen both affected the performance of the two Elodea species. Interactive effects of light and nitrogen were also obvious: increase in light stimulated growth twice as much under high nitrogen concentrations $(2.5$ and $5 \mathrm{mg}$ $\left.\mathrm{L}^{-1}\right)$ than at lower $\mathrm{N}$ levels $\left(0.05 \mathrm{mg} \mathrm{L}^{-1}\right)$. Therefore, the same growth rate can be obtained under different conditions: reduced 


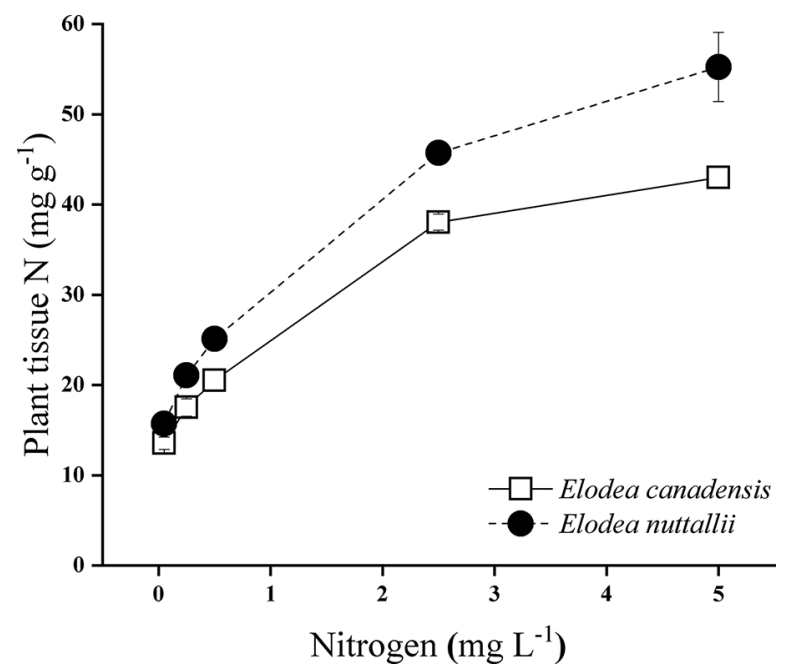

FIGURE 7 | Plant tissue nitrogen concentration of Elodea species grown at different nitrogen concentrations at the highest light intensity $\left(180 \mu \mathrm{mol} \mathrm{m}{ }^{-2}\right.$ $\left.\mathrm{S}^{-1}\right)($ mean $\pm \mathrm{SD}, n=4)$.



FIGURE 8 | Total nitrogen concentration of the medium with Elodea species grown under $5 \mathrm{mg} \mathrm{L}^{-1}$ initial $\mathrm{N}$ concentration at different light levels (mean \pm $\mathrm{SD}, n=4)$.

light conditions but with more nitrogen gave similar yields as lower nitrogen and more light.

\section{Light Compensation Point, Weight Loss in the Dark}

The light compensation $\left(I_{\mathrm{c}}\right)$ point of E. canadensis grown under optimal nitrogen supply in the present study closely approximates the results of Madsen and Sand-Jensen (1994) who kept the plants under an optimal carbon supply. They also found a sharp increase in the light compensation point under lowered inorganic carbon supply as with nitrogen levels in the present study. E. canadensis had a much higher light compensation point $\left(I_{\mathrm{c}}\right)$ than $E$. nuttallii. This indicates that the latter species may survive better under more shaded conditions, such as turbid water, periphytic algae, or below a dense mat of floating plants (Angelstein and Schubert, 2009; van Gerven et al., 2015). Weight loss in the dark of E. canadensis was approximately two times higher than recorded by Madsen and Sand-Jensen (1994), which can be explained by dark respiration being lower at low temperatures. Interestingly, E. nuttallii showed lower weight loss in the dark than E. canadensis, and this might be an important indication that E. nuttallii can tolerate darkness for a longer period.

\section{Change in Chlorophyll Concentration}

Since nitrogen is a crucial component of chlorophyll, it is not surprising that the total chlorophyll concentration of both Elodea species was strongly affected by the availability of nitrogen. Therefore, our results are in line with the findings of many authors (Szabó et al., 2005; Szabó et al., 2010; Zhao et al., 2010). In general, E. nuttallii had a higher chlorophyll concentration than E. canadensis and plants showed a peak in chlorophyll under rather low light conditions $\left(10-28 \mu \mathrm{mol} \mathrm{m} \mathrm{m}^{-2} \mathrm{~s}^{-1}\right)$ as was also found by Madsen and Sand-Jensen (1994). In complete darkness, however, both species lost some chlorophyll content since they did not receive sufficient energy to sustain chlorophyll synthesis and maintaining the photosynthetic apparatus for a long period is uneconomical (Raven, 1984).

\section{Change in Photosynthetic Efficiency}

The actual photosynthetic efficiency of both Elodea species was slightly decreased under low nitrogen supply which is in line with the studies of Cruz et al. (2003) and Huang et al. (2004) and indicates that nitrogen deficiency causes damage to PSII reaction centers (Verhoeven et al., 1997; Lu et al., 2001). Furthermore, nitrogen is essential for protein synthesis in order to sustain or rebuild the photosynthetic apparatus (Evans, 1989). Under low light levels $\left(0-10 \mu \mathrm{mol} \mathrm{m} \mathrm{m}^{-2} \mathrm{~s}^{-1}\right)$ parallel to the RGR results, $E$. nuttallii showed marginally but significantly higher actual photosynthetic efficiency than E. canadensis. Higher $\Phi_{\text {PSII }}$ efficiency of $E$. nuttallii can be taken as a characteristic related to shade tolerance only in combination with the lower lc which the primary factor here. Remarkably, after twelve days of incubation in total darkness, both Elodea species still showed significant photosynthetic activity indicating that if oxygen is not limited, they can tolerate dark conditions for extended periods.

\section{Morphological and Ecophysiological Strategies}

Both Elodea species showed a high ability to acclimate to various light and nutrient levels, and they shared many similarities in their ecophysiological and morphological responses (Figure 9). Under high nitrogen levels the plants seem to invest more energy in photon capture than in nutrient uptake as evidenced by the reduced root-shoot ratio (James et al., 2006), light compensation point, increased chlorophyll concentration and photochemical efficiency which is in line with the studies of Li et al. (2016) and Gautam et al. (2016). An alternative explanation could be that 




FIGURE 9 | The effect of light levels and nitrogen on the ecophysiological and phenotypic traits of Elodea nuttallii resulting in invasion success. Solid lines represent stimulation, dashed lines represent inhibition processes. $\mathrm{N}+$ and $\mathrm{N}$ - indicate the stimulating or inhibitory impacts of increased nitrogen supply, IO light compensation point.

plants invest less in root biomass since less below-ground biomass is necessary for nutrient uptake in $\mathrm{N}$ rich water (Madsen and Cedergreen, 2002). At low light levels, similarly as high nitrogen levels, the plants also redirected resources towards a more efficient photon capture rather than nutrient uptake as proved by the increase in the chlorophyll concentration in the leaves together with a higher actual photochemical efficiency of PSII, increased shoot elongation per unit biomass and reduced allocation to root formation and reduced nutrient removal (Figure 9). At low light levels, E. nuttallii the stronger invader showed drop in branching.

Increase in chlorophyll concentration with lowering light is well in line with the results of Angelstein and Schubert (2009). In our study, both morphological (root-shoot ratio) and ecophysiological (actual photochemical efficiency of PSII, chlorophyll concentration) changes were similar to those observed in response to decreased light intensities caused by shading from floating vegetation which has been found in other submerged macrophytes (Janes et al., 1996; Forchhammer, 1999; Lu et al., 2013).

\section{Displacement Mechanisms}

Our laboratory study showed that E. canadensis had a slightly higher growth rate than $E$. nuttallii, supporting the view that both species responded similarly to changing light and N-levels. The directions of the differences were always similar; however the magnitude was different (Supplementary Table 2). The replacement of $E$. canadensis by $E$. nuttallii indicates that there must be differences between both species. From our laboratory experiment we are not able to infer the competitive abilities of the two Elodea since we had no mixed cultures (McCreary, 1991). However, it is evident that in a competition experiment, the competition itself may mask relevant mechanisms but also small differences between the two species. The data of tissue $\mathrm{N}$ concentration and the decrease in nitrogen concentration in the water indicated that under higher light intensity E. nuttallii has much stronger nitrogen removal capacity than E. canadensis (Figure 8, Supplementary Table 2). This trait may especially advantageous in waters with suboptimal nitrogen concentration. Furthermore, E. nuttallii exhibited less reduction in biomass and showed lower light compensation point than $E$. canadensis and seemed thus more shade tolerant (Supplementary Table 2). In hypertrophic ditches and ponds, thick layers of floating algal mat reduce light conditions (Hillebrand, 1983) in spring whereas in summer floating vegetation may cause dense shade on submerged plants reducing their growth (Scheffer et al., 2003; van, Zuidam and Peeters, 2013; van Gerven et al., 2015). In addition, at high trophic levels $E$. nuttallii has much less periphytic algal biomass than E. canadensis (James et al., 2006) thus the new invader may have an even greater advantage for light capture.

Our former results pointed out that E. canadensis tends to produce dense canopy with numerous branches even under low nitrogen and light levels. Thus, E. canadensis shows less apical growth that might be a disadvantage in the competition for light with E. nuttallii. On the contrary, E. nuttallii invests much more on apical shoot elongation and thereby gain a better position for light capture (Szabó et al., 2019) (Figure 9, Supplementary Table 2). Under low light levels, E. nuttallii is able to elongate much faster due to its higher elongation and lower branching degree abilities and lower light compensation point (Figure 9). Thus, the shoots of E. nuttallii are able to achieve optimal light conditions sooner. Near to the water surface under high trophic level, they 
can form a dense canopy (Kuni, 1984) due to their increased branching degree, resulting in a strong shading for other submerged plants (Figure 9). Therefore, under hypertrophic conditions stands of E. nuttallii may develop sooner than that of E. canadensis and the stronger invader can sustain its stable dominance not only against other submerged plants but against algae and floating vegetation as well (Szabó et al., 2010).

Field observations showed that the replacements of $E$. canadensis by E. nuttallii occurred under hypertrophic conditions with nitrogen concentrations above $2 \mathrm{mg} \mathrm{L}^{-1}$ (Knoben and Peeters, 1997; van Zuidam and Peeters, 2013; Kočic et al., 2014). Actually, in this study, the niche for light requirement of $E$. nuttallii was narrower than that of $E$. canadensis. Therefore, our results partly contradict the idea of Higgins and Richardson (2014) who concluded that stronger invaders have broader physiological niches. However, this kind of adaptation to achieve fitness and invasiveness was more optimal under shaded conditions. These ecophysiological differences between the two species provide insights that could improve the understanding of the mechanisms of invasion processes under varying light and nutrient levels (Supplementary Table 2, Figure 9).

\section{DATA AVAILABILITY STATEMENT}

The datasets generated for this study are available on request to the corresponding author.

\section{REFERENCES}

Angelstein, S., and Schubert, H. (2009). Light acclimatisation of Elodea nuttallii grown under ambient DIC conditions. Plant Ecol. 202, 91-101. doi: 10.1007/ s11258-008-9500-4

Barko, J. W., and Smart, R. M. (1985). Laboratory culture of submerged freshwater macrophytes on natural sediments. Aquat. Bot. 21, 251-263. doi: 10.1016/ 0304-3770(85)90053-1

Barko, J. W., Hardin, D. G., and Matthews, M. S. (1982). Growth and morphology of submerged freshwater macrophytes in relation to light and temperature. Can. J. Bot. 60, 877-887. doi: 10.1139/b82-113

Barrat-Segretain, M.-H., and Elger, A. (2004). Experiments on growth interactions between two invasive macrophyte species. J. Veg. Sci. 15, 109-114. doi: 10.1111/ j.1654-1103.2004.tb02243.x

Barrat-Segretain, M.-H., Elger, A., Sagnes, P., and Puijalon, S. (2002). Comparison of three life-history traits of invasibe Elodea canadensis Michx and Elodea nuttallii (Planch.) H. St. John. Aquat. Bot. 74, 299-313. doi: 10.1016/S03043770(02)00106-7

Barrat-Segretain, M.-H. (2001). Invasive species in the Rhône River floodplain (France): replacement of Elodea canadensis Michaux by E. nuttallii St. John in two former river channels. Arch. Hydrobiol. 152, 237-251.

Barrat-Segretain, M.-H. (2004). Growth of Elodea canadensis and Elodea nuttallii in monocultures and mixture under different light and nutrient conditions. Arch. Hydrobiol. 161, 133-144. doi: 10.1127/0003-9136/2004/0161-0133

Barrat-Segretain, M.-H. (2005). Competition between invasive and indigenous species: impact of spatial pattern and developmental stage. Plant Ecol. 180, 153-160. doi: 10.1007/s11258-004-7374-7

Best, E. P. H., Buzzelli, C. P., Bartell, S. M., Wetzel, R. L., Boyd, W. A., Doyle, R. D., et al. (2001). Modeling submerged macrophyte growth in relation to underwater light climate: modeling approaches and application potential. Hydrobiologia 444, 43-70. doi: 10.1023/A:1017564632427

\section{AUTHOR CONTRIBUTIONS}

SS designed and performed the experiments. PN analyzed the chemical composition of the plants. SS, EP, and BL analyzed the data. SS, BL, GB, SV, and EP wrote the manuscript.

\section{FUNDING}

This work was supported by GINOP grant (2.3.2-15-201600019) and OTKA grants (FK127939 and KH129520). BL was supported by the Bolyai János Research Scholarship of the Hungarian Academy of Sciences and by the New National Excellence Program of the Ministry of Innovation and Technology (UNKP-19-4-DE-193).

\section{ACKNOWLEDGMENTS}

We thank Ferenc Mónus for his help in statistics. This article does not contain any studies with human participants or animals performed any of the authors.

\section{SUPPLEMENTARY MATERIAL}

The Supplementary Material for this article can be found online at: https://www.frontiersin.org/articles/10.3389/fpls.2019. 01747/full\#supplementary-material

Cao, T., Ni, L., Xie, P., Xu, J., and Zhang, M. (2011). Effects of moderate ammonium enrichment on three submerged macrophytes under contrasting light availability. Freshw. Biol. 56, 1620-1629. doi: 10.1111/j.13652427.2011.02601.x

Chambers, P. A., and Kalff, J. (1987). Light and nutrients in the control of aquatic plant community structure. I. In situ experiments. J Ecol. 75, 611-619. doi: $10.2307 / 2260193$

Chambers, P. A. (1987). Light and nutrients in the control of aquatic plant community structure. II. In situ observation. J. Ecol. 75, 621-628. doi: 10.2307/ 2260194

Cruz, J. L., Mosquim, P. R., Pelacani, C. R., Araújo, W. L., and DaMatta, F. M. (2003). Photosynthesis impairment in cassava leaves in response to nitrogen deficiency. Plant Soil. 257, 417-423. doi: 10.1023/A:1027353305250

Erhard, D., and Gross, E. M. (2006). Allelopathic activity of Elodea canadensis and Elodea nuttallii against epiphytes and phytoplankton. Aquat. Bot. 85, 203-211. doi: 10.1016/j.aquabot.2006.04.002

Espinar, J. L., Díaz-Delgado, R., Bravo-Utrera, M. A., and Vilà, M. (2015). Linking Azolla filiculoides invasion to increased winter temperatures in the Doñana marshland (SW Spain). Aquat. Invasions 10, 17-24. doi: 10.3391/ ai.2015.10.1.02

Evans, J. R. (1989). Photosynthesis and nitrogen relationships in leaves of C3 plants. Oecologia 78, 9-19. doi: 10.1007/BF00377192

Forchhammer, N. C. (1999). Production potential of aquatic plants in systems mixing floating and submerged macrophythes. Freshw. Biol. 41, 183-191.doi: 10.1046/j.1365-2427.1999.00390.x

Gautam, P., Lal, B., Tripathi, R., Shahid, M., Baig, M. J., Raja, R., et al. (2016). Role of silica and nitrogen interaction in submergence tolerance of rice. Environ. Exp. Bot. 125, 98-109. doi: 10.1016/j.envexpbot.2016.02.008

Genty, B., Briantais, J.-M., and Baker, N. R. (1989). The relationship between the quantum yield of photosynthetic electron transport and quenching of 
chlorophyll fluorescence. Biochim. Biophys. Acta 990, 87-92. doi: 10.1016/ S0304-4165(89)80016-9

Grudnik, Z. M., and Germ, M. (2013). Spatial pattern of native species Myriophyllum spicatum and invasive alien species Elodea nuttallii after introduction of the later one into the Drava River (Slovenia). Biologia 68, 202-209. doi: 10.2478/s11756-013-0006-8

Grudnik, Z. M., Jelenko, I., and Germ, M. (2014). Influence of abiotic factors on invasive behaviour of alien species Elodea nuttallii in the Drava River (Slovenia). Ann. Limnol-Int. J. Limn. 50, 1-8. doi: 10.1051/limn/2013065

Higgins, S. I., and Richardson, D. M. (2014). Invasive plants have broader physiological niches. P. Nat. Acad. Sci. USA. 111, 10610-10614. doi: 10.1073/pnas.1406075111

Hillebrand, H. (1983). "Development and dynamics of floating clusters of filamentous algae," in Periphyton of Freshwater Ecosystems. Ed. R. G. Wetzel (The Hague: Dr. W Junk Publishers).

Huang, Z. A., Jiang, D. A., Yang, Y., Sun, J. W., and Jin, S. H. (2004). Effects of nitrogen deficiency on gas exchange, chlorophyll fluorescence, and antioxidant enzymes in leaves of rice plants. Photosynthetica 42, 357-367. doi: 10.1023/B: PHOT.0000046153.08935.4c

James, C. S., Eaton, J. W., and Hardwick, K. (1999). Competition between three submerged macrophytes, Elodea canadensis Michx. Elodea nuttallii (Planch.) St John and Lagarosiphon major (Ridl.) Moss. Hydrobiologia 415, 35-40. doi: 10.1023/A:1003802205092

James, C. S., Eaton, J. W., and Hardwick, K. (2006). Responses of three invasive aquatic macrophytes to nutrient enrichment do not explain their observed field displacements. Aquat. Bot. 84, 347-353. doi: 10.1016/ j.aquabot.2006.01.002

Janes, R. A., Eaton, J. W., and Hardwick, K. (1996). The effects of floating mats of Azolla filiculoides Lam. and Lemna minuta Kunth on the growth of submerged macrophytes. Hydrobiologia 340, 23-26. doi: 10.1007/978-94011-5782-7_5

Király, G., Steták, D., and Bányász, Á. (2007). Spread of invasive macrophythes in Hungary. Neobiota 7, 123-130.

Knoben, R. A. E., and Peeters, E. T. H. M. (1997). Eco-atlas van waterorganismen. STOWA publication no. 97-38.

Kočic, A., Horvatic, J., and Jelaska, D. (2014). Distribution and morphological variations of invasive macrophytes Elodea nuttallii (Planch.) H. St. John and Elodea canadensis Michx in Croatia. Acta Bot. Croat. 73, 437-446. doi: 10.2478/botcro-2014-0011

Kuni, H. (1982). The critical water temperature for active growth of Elodea nuttallii (Planch.) St. John. Japanese J. Ecol. 32, 111-112. doi: 10.18960/ seitai.32.1_111

Kuni, H. (1984). Seasonal growth and profile structure development of Elodea nuttallii (Planch.) St. John. In pond Ojaka-Ike, Japan. Aquat. Bot. 18, 239-247. doi: 10.1016/0304-3770(84)90065-2

Lürling, M., van Geest, G., and Scheffer, M. (2006). Importance of nutrient competition and allelopathic effects in suppression of the green alga Scenedesmus obliquus by the macrophytes Chara, Elodea and Myriophyllm. Hydrobiologia 556, 209-220. doi: 10.1007/s10750-005-1168-3

Li, J., Guo, Q., Zhang, J., Korpelainen., H., and Li, C. (2016). Effects of nitrogen and phosphorus supply on growth and physiological traits of two Larix species. Environ. Exp. Bot. 230, 206-215. doi: 10.1016/j.envexpbot.2016. 06.006

Lichtentaler, K. H. (1987). Chlorophylls and carotenoids: pigments of photosynthetic biomembranes. Method. Enzymol. 148, 350-382. doi: 10.1016/0076-6879(87)48036-1

Lu, C., Zhang, J., Zhang, Q., Li, L., and Kuang, T. (2001). Modification of photosystem II photochemistry in nitrogen deficient maize and wheat plants. J. Plant Physiol. 158, 1423-1430. doi: 10.1078/0176-1617-00501

Lu, J., Wang, Z., Xing, W., and Liu, G. (2013). Effects of substrate and shading on the growth of two submerged macrophytes. Hydrobiologia 700, 157-167. doi: 10.1007/s10750-012-1227-5

Lund, J. W. G. (1979). The mystery of Elodea Michx. Watsonia 12, 388.

Madsen, T. V., and Cedergreen, N. (2002). Sources of nutrients to rooted submerged macrophytes growing in a nutrient-rich stream. Freshw. Biol. 47, 283-291. doi: 10.1046/j.1365-2427.2002.00802.x
Madsen, T. V., and Sand-Jensen, K. (1994). The interactive effects of light and inorganic carbon on aquatic plant growth. Plant Cell. Environ. 17, 955-962. doi: 10.1111/j.1365-3040.1994.tb00324.x

Madsen, T. V., Halm, P., and Johansen, J. (1998). Effects of inorganic carbon supply on the nitrogen requirement of two submerged macrophytes, Elodea canadensis and Callitriche cophocarpa. Aquat. Bot. 62, 95-106. doi: 10.1016/ S0304-3770(98)00087-4

Marwood, C. A., Solomon, K. R., and Greenberg, B. M. (2001). Chlorophyll fluorescence as a bioindicator of effects on growth in aquatic macrophythes from mixtures of polycyclic aromatic hydrocarbons. Environ. Toxicol. Chem. 20, 890-898. doi: 10.1002/etc.5620200425

McCreary, N. J. (1991). Competition as a mechanism of submerged macrophyte community structure. Aquat. Bot. 41, 177-193. doi: 10.1016/0304-3770(91)90043-5

Morris, K., Harrison, K. A., Bailey, C. P. E., and Boon, P. I. (2004). Domain shifts in the aquatic vegetation of shallow urban lakes: the relative roles of low light and anoxia in the catastrophic loss of the submerged angiosperm Vallisneria americana. Mar. Freshwater. Res. 55, 749-758. doi: 10.1071/MF03193

Ot'ahel'ová, H., and Valachovič, M. (2002). Effects of the Gabčíkovo hydroelectricstation on aquatic vegetation of the Danube river (Slovakia). Preslia 74, 323-331.

Peeters, E. T. H. M., Van Zuidam, J. P., Van Zuidam, B. G., Van Nes, E. H., Kosten, S., Heuts, P. G. M., et al. (2013). Changing weather conditions and floating plants in temperate drainage ditches. J. Appl. Ecol. 50, 585-593. doi: 10.1111/ 1365-2664.12066

Phillips, G. L., Eminson, D., and Moss., B. (1978). A mechanism to account for macrophyte decline in progressively eutrophicated freshwaters. Aquat. Bot. 4, 103-126. doi: 10.1016/0304-3770(78)90012-8

Raven, J. A. (1984). Energetics and transport in aquatic plants (New York: Alan R. Liss).

Robach, F., Thiébaut, G., and Tremolières, M. (1995). Phosphorus sources for aquatic macrophytes in runing waters: water or sediment? Acta Bot. Gallica 142, 719-731. doi: 10.1080/12538078.1995.10515296

Sand-Jensen, K., and Madsen, T. V. (1991). Minimum light requirements of submerged freshwater macrophytes in laboratory growth experiments. J. Ecol. 79, 749-764. doi: 10.2307/2260665

Scheffer, M., Szabó, S., Gragnani, A., Van Nes, E. H., Rinaldi, S., Kautsky, N., et al. (2003). Floating plant dominance as a stable state. P. Natl. Acad. Sci. USA. 100, 4040-4045. doi: 10.1073/pnas.0737918100

Simpson, D. A. (1984). A short history of the introduction and spread of Elodea Michx in the British Isles. Watsonia 15, 1-9. doi: 10.1.1.666.1032\&rep= rep 1 \&type $=$ pdf

Simpson, D. A. (1990). Displacement of Elodea canadensis Michx by Elodea nuttallii (Planch.) H. St John in the British Isles. Watsonia 18, 173-177. doi: 10.1.1.666.1032\&rep=rep1\&type $=$ pdf

Sipos, V. K., Kohler, A., Köder, M., and Janauer, G. (2003). Macrophyte vegetation of Danube canals in Kiskunság (Hungary). Arch. Hydobiol. Suppl. Large Rivers 14, 143-166. doi: 10.1127/lr/14/2003/143

Snel, J. F. H., Vos, J. H., Gylstra, R., and Brock, T. C. M. (1998). Inhibition of photosystem II (PSII) electron transport as a convenient endpoint to assess stress of the herbicide linuron on freshwater plants. Aquat. Ecol. 32, 113-123. doi: 10.1023/A:1009971930626

Szabó, S., Roijackers, R. M. M., Scheffer, M., and Borics, G. (2005). The strength of limiting factors for duckweed during algal competition. Arch. Hydobiol. 164, 127-140. doi: 10.1127/0003-9136/2005/0164-0127

Szabó, S., Scheffer, M., Roijackers, R., Waluto, B., Braun, M., Nagy, P., et al. (2010). Strong growth limitation of a floating plant (Lemna gibba) by submerged macrophyte (Elodea nuttallii) under laboratory conditions. Freshw. Biol. 55, 681-690. doi: 10.1111/j.1365-2427.2009.02308.x

Szabó, S., Peeters, E. T. H. M., Várbíró, G., Borics, G., and Lukács, B. A. (2019). Phenotypic plasticity as a clue for the invasion success of the submerged aquatic plant Elodea nuttallii. Plant Biol. 21, 54-63. doi: 10.1111/plb.12918

van Gerven, L. P. A., de Klein, J. J. M., Gerla, D. J., Kooi, B. W., Kuiper, J. J., and Mooij, W. M. (2015). Competition for light and nutrients in layered communities of aquatic plants. Am. Nat. 186, 72-83. doi: 10.1086/681620

van, Zuidam, J. P., and Peeters, E. T. H. M. (2013). Occurrence of macrophyte monocultures in drainage ditches relates to phosphorus in both sediment and water. SpringerPlus 2, 564. doi: 10.1186/2193-1801-2-564 
Verhoeven, A. S., Demmig-Adams, B. I. I. I., and Adams., W. W. (1997). Enhanced employment of the xanthophyll cycle and thermal energy dissipation in spinach exposed to high light and N stress. Plant Physiol. 113, 817-824. doi: $10.1104 / \mathrm{pp} .113 .3 .817$

Vilà, M., and Weiner, J. (2004). Are invasive plants species better competitors than native plant species? - evidence from pair-wise experiments. Oikos 105, 229238. doi: 10.1111/j.0030-1299.2004.12682.x

Zhao, X., Mao, Z., and Xu, J. (2010). Gas exchange, chlorophyll and growth responses of Betula platyphylla seedlings to elevated $\mathrm{CO}_{2}$ and nitrogen. Int. J. Biol. 2, 143-149. doi: 10.1.1.669.7631\&rep=rep1\&type $=$ pdf
Conflict of Interest: The authors declare that the research was conducted in the absence of any commercial or financial relationships that could be construed as a potential conflict of interest.

Copyright (C) 2020 Szabó, Peeters, Borics, Veres, Nagy and Lukács. This is an openaccess article distributed under the terms of the Creative Commons Attribution License (CC BY). The use, distribution or reproduction in other forums is permitted, provided the original author(s) and the copyright owner(s) are credited and that the original publication in this journal is cited, in accordance with accepted academic practice. No use, distribution or reproduction is permitted which does not comply with these terms. 